\title{
Characterization of a Tospovirus Isolate of Iris Yellow Spot Virus Associated with a Disease in Onion Fields in Brazil
}

L. Pozzer and I. C. Bezerra, Embrapa/Hortaliças, Km 09, Rodovia Brasília Anápolis, CEP: 70.359-970, Brasília, DF, Brazil; R. Kormelink, M. Prins, and D. Peters, Wageningen Agricultural University, Laboratory of Virology, Binnenhaven 11, 6709 PD, Wageningen, The Netherlands; R. de O. Resende, Universidade de Brasília, Departamento de Biologia Celular, CEP: 70.919-970, Brasília, DF, Brazil; and A. C. de Ávila, Embrapa/Hortaliças, Km 09, Rodovia Brasília Anápolis, CEP: 70.359-970, Brasília, DF, Brazil

\begin{abstract}
Pozzer, L., Bezerra, I. C., Kormelink, R., Prins, M., Peters, D., Resende, R. de O., and de Ávila, A. C. 1999. Characterization of a tospovirus isolate of iris yellow spot virus associated with a disease in onion fields in Brazil. Plant Dis. 83:345-350.

A tospovirus from onion causing a disease known as "sapeca" by growers in Brazil was characterized. Symptoms on onion consisted of numerous eyelike spots on the leaves and flower stalks resulting in flower abortion. Nicotiana benthamiana and N. rustica were the only systemic hosts experimentally found. Double antibody sandwich enzyme-linked immunosorbent assay (DAS-ELISA) experiments demonstrated that this virus was serologically related to iris yellow spot virus (IYSV), a tospovirus recently described in the Netherlands. This virus, from onion, based on an amino acid sequence identity of $90.5 \%$ for the $\mathrm{N}$ gene protein, is regarded as a strain of IYSV and is designated IYSV $_{\mathrm{BR}}$. This $10 \%$ divergence in the nucleocapsid protein may represent an adaptation of the virus to distinct ecological niches.
\end{abstract}

In 1981, a tospovirus occurring in onions in Brazil, reported to be tomato spotted wilt virus (TSWV), was found in Rio Grande do Sul in the southern part of Brazil (6). Tospovirus infections were not observed in onion fields again until 1994, when severe infections occurred in SubMedio São Francisco in the states of Bahia and Pernambuco in the northeastern part of Brazil (22). The symptoms began as necrotic eyelike spots on leaves and flower stalks, which led to the death of all flowers. The incidence of this disease, called "sapeca" by the growers, often reached levels of $100 \%$, resulting in a total loss of bulb and seed production. In SubMédio São Francisco, tospovirus infections cause very serious problems in tomato, sweet pepper, and lettuce crops, but appear to be caused only by groundnut ringspot virus (GRSV) $(8,20)$.

Infections by TSWV, the type member of the genus Tospovirus, have been reported in different crops in Brazil since the 1940s (3). Two more distinct species, i.e., tomato chlorotic spot virus (TCSV) and GRSV, have been found on several occasions (20), and two possible new species isolated from chrysanthemum and zucchini have recently been reported $(12,23)$.

Corresponding author: Antonio Carlos de Ávila E-mail: avila@ cnph.embrapa.br

Accepted for publication 8 December 1998.

Publication no. D-1999-0126-01R

(C) 1999 The American Phytopathological Society
The occurrence of tospoviruses in onion (Allium cepa L.) has also been reported in the United States. One virus was identified as impatiens necrotic spot virus (INSV), and the other appeared to be an unassigned tospovirus species that did not cross-react with antisera to TSWV $(15,18)$. Recently, a tospovirus named iris yellow spot virus (IYSV) was isolated from iris and leek in the Netherlands (2). A serologically similar virus was isolated from onions in Israel (13).

Here we report on the phenotypical and molecular characterization of the Brazilian onion isolate (designated BR-10) and discuss its taxonomic position within the genus Tospovirus of the family Bunyaviridae.

\section{MATERIALS AND METHODS}

Multiplication and preservation of the virus isolate. The isolate $B R-10$, collected in the northeastern part of Brazil, was propagated by mechanical inoculation in Nicotiana benthamiana plants and grown in a greenhouse. Samples of this virus were stored at $-80^{\circ} \mathrm{C}$ in stem segments of naturally infected onion plants or leaf material from mechanically inoculated $N$. benthamiana plants.

Host range. Stem segments of naturally infected onion plants showing symptoms characteristic for this isolate, and of systemically infected $N$. benthamiana leaf material, were triturated in $0.01 \mathrm{M}$ sodium phosphate buffer ( $\mathrm{pH}$ 7.0) containing 0.01 $\mathrm{M}$ sodium sulfite. Test plant species were inoculated, monitored for symptoms for 3 weeks, and checked for virus infection by double antibody sandwich enzyme-linked immunosorbent assay (DAS-ELISA).
Purification of nucleocapsid material. Nucleocapsids were purified from systemically infected $N$. benthamiana 2 weeks after inoculation according to the method of de Ávila et al. (7).

Polyclonal antiserum production. $\mathrm{Pu}-$ rified nucleocapsids were emulsified with Freund's complete adjuvant (1:1) for the first immunization and with incomplete adjuvant injection in the three following injections. The subcutaneous injections were made at intervals of 1 week, each with $100 \mu \mathrm{g}$ of $\mathrm{N}$ protein in a volume of 1 $\mathrm{ml}$. Antibodies to $N$. benthamiana constituents were eliminated from the antisera by adding a few droplets of healthy plant sap. The IgG fraction $(1 \mathrm{mg} / \mathrm{ml})$ was isolated by ammonium sulfate precipitation, eluted over a DEAE-Sephacel column (Sigma, St. Louis, MO) and conjugated to alkaline phosphatase $(1 \mathrm{mg} / \mathrm{ml})$.

Molecular weight determination. The molecular weight of the $\mathrm{N}$ protein was estimated on a $12 \%$ sodium dodecyl sulfate-polyacrylamide gel electrophoresis (SDS-PAGE) gel and stained with Coomassie Brilliant Blue (CBB). Low molecular weight size markers ranging from 14.4 to $97.4 \mathrm{kDa}$ (Promega, Madison, WI) were included for molecular weight determination.

ELISA. The isolate BR-10 was compared in homologous and heterologous DAS-ELISA (1) reactions with tospovirus species TSWV, TCSV, GRSV, INSV, and IYSV using polyclonal anti-N sera directed to the respective viruses. Extracts of $N$. benthamiana plants with these viruses served as an antigen source approximately 2 weeks after inoculation, along with healthy plant controls. ELISA values were read with a Labsystems Multiskan Biochromatic ELISA Reader. The concentration of the $\mathrm{N}$ protein was measured by the Biorad protein assay. Comparative serological studies with WSMV were made using an immuno dot blot assay.

Extraction of viral RNA. Viral RNA was extracted from purified nucleocapsid fractions using the phenol-chloroform method as described by de Ávila et al. (7). RNA was analyzed on $1 \%$ agarose gels containing 5\% formaldehyde (26).

Amplification and cloning of the $\mathbf{N}$ gene. First strand cDNA synthesis was primed on viral RNA using primer IY1 $\left(5^{\prime}\right.$ 


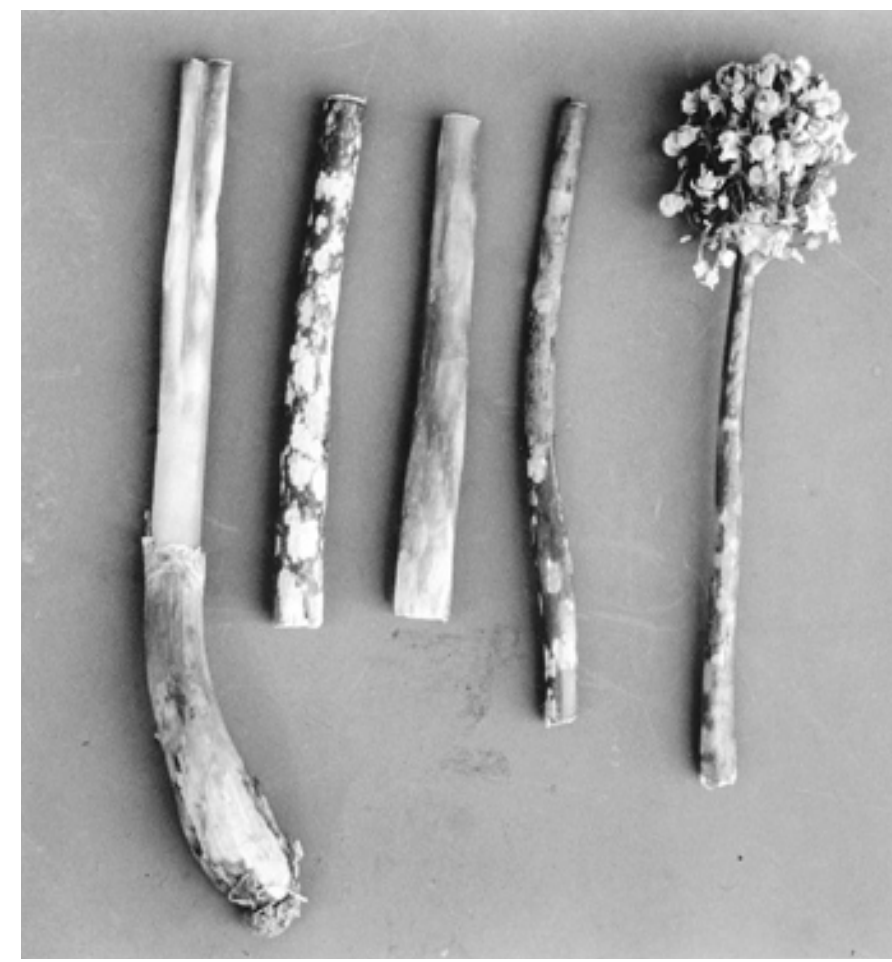

Fig. 1. Symptoms on naturally infected onion (Allium cepa) plants. Necrotic eyelike spots on the flower stem and the umbel showing wilting and abortion of flowers.
CCCGAGGATCCATGGCTACCGTTAG GG 3'), complementary to nucleotides 3,020 to 3,037 of IYSV S RNA (2). Complementary DNA was subsequently used as template in a PCR reaction using IY1 and IY2 (5' CCCGAGGATCCAAATTAATTATATCTATCTTTC $3^{\prime}$ ). The latter is identical to nucleotides 2,211 to 2,236 of the IYSV S RNA. Amplification was performed using $5 \mathrm{U}$ of Taq DNA polymerase (CENTEBIO) for 30 cycles at $94^{\circ} \mathrm{C}$ for 1 min (denaturation), $48^{\circ} \mathrm{C}$ for $2 \mathrm{~min}$ (annealing), and $72^{\circ} \mathrm{C}$ for 2 min (elongation). After a final extension reaction at $72^{\circ} \mathrm{C}$ for 7 min, PCR fragments were resolved on a $1 \%$ agarose gel, and fragments of the expected size, containing the BR-10 N gene, were gel-purified and cloned into pGEM-T vector (Pharmacia, Uppsala, Sweden). Clones of interest were tested for their $\mathrm{S}$ RNA specificity on Northern blots, and its nucleotide sequence was determined.

Sequence homology studies. Nucleotide sequences were determined on an automatic sequencer according to the dideoxy chain-termination method (27). The nucleotide sequences obtained were analyzed and compared with the sequences in the data bank of Genbank and EMBL and

\section{圈HEALTHY ETSWV ETCSV SGRSV IINSV DIYSV EBR-10}

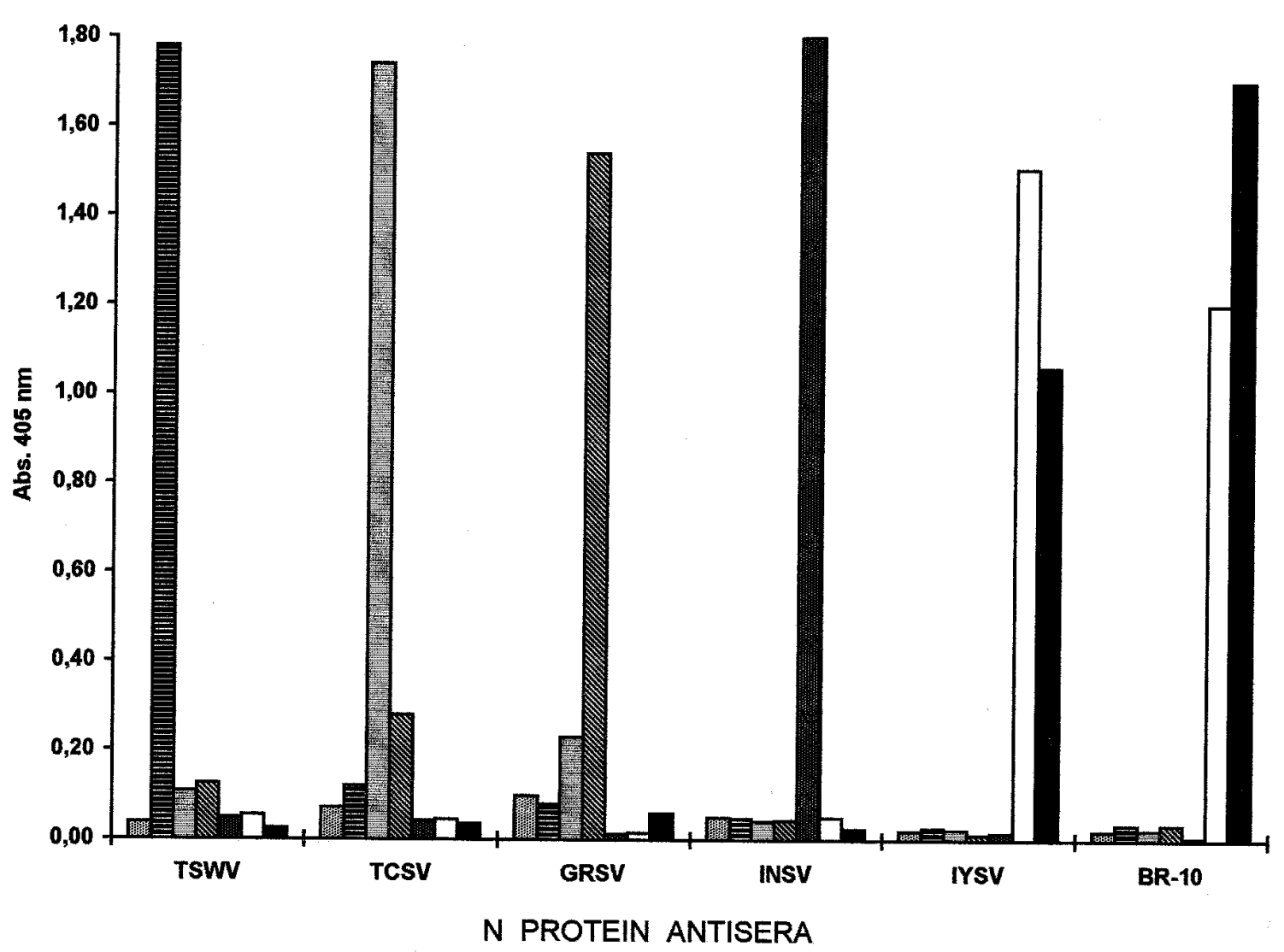

Fig. 2. Serological reactions among six tospoviruses showing amount of relatedness using polyclonal antisera against their respective $\mathrm{N}$ proteins and infected plant extracts as antigen source. 
the deduced amino acid sequences with the data bank of SwissProt and PIR using the algorithm GCG packages FASTA, BESTFIT, and PILEUP (10).

\section{RESULTS}

Host range of BR-10. Particles characteristic in shape and size for tospoviruses were found in tissues of naturally infected onion and mechanically inoculated $N$. benthamiana plants (data not shown), showing that the naturally infected onion material was indeed infected by a tospovirus. The absence of any cross-reaction with polyclonal anti-N serum directed toward TSWV led to the first indication that a tospovirus could be involved. As further proof, the experimental host range was limited to Chenopodium amaranticolor, $C$. quinoa, Datura stramonium, Gomphrena globosa, and Portulaca oleracea with local lesions on the inoculated leaves. Tobaccos $N$. benthamiana and Nicotiana rustica, and onion, were the only species that became systemically infected. The veins of inoculated leaves of $N$. benthamiana became necrotic; the leaves crinkled and finally died. The percentage of $N$. rustica plants that became infected varied among inoculations and drastically decreased with the

ATG GCT ACC GTT AGG GTA AAA GCT TCA GAA ATC GAG AAA CTT CTC TCT $\begin{array}{llllllllllllllll}M & A & T & V & R & V & K & A & S & E & I & E & K & L & L & S\end{array}$ GGT GGA GAT GCA GAT GTG GTA ATT GAA TCT GAT GAA ACT GAA GGA TTC $\begin{array}{llllllllllllllll}G & G & D & A & D & V & V & I & E & S & D & E & T & E & G & F\end{array}$

AAT TTC AAG AGC TTT GTG GTG GCA AAT GAG GGT ATC CGA ATG ACA TTC

337 AAC GAA AAG GAA AAA CAG AAA ATG TAT GAA AAA ATC TGC GGG CTT CCT $\begin{array}{llllllllllllllll}N & E & K & E & K & Q & K & M & Y & E & K & I & C & G & I & P\end{array}$

385 CTG GTG AGT GCA TAT GGT TTG AAA CCT AGC GAC AAG TTT GAT GCA ACC $\begin{array}{llllllllllllllll}I & V & S & A & Y & G & L & K & P & S & D & K & F & D & A & T\end{array}$

433 ACA GCC AGG ATC ATG CTA ACA CTA GGC GGT CCT CTC ATC TTA CTG GCA

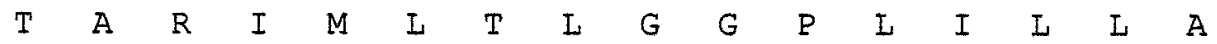

481 AGT CTT GAC AGC TTT GCT GCA GCT GCT CTT CCT TTA GCT TAT TTC CAG $\begin{array}{llllllllllllllll}S & \text { L } & D & S & F & A & A & A & A & \text { L } & \text { P } & \text { L } & \text { A } & \text { Y } & F & Q\end{array}$

529 AAT GTG AAA AAA GAA GCA CTT GGT ATA AGC AGA TTC TCA ACT TAT GAG $\begin{array}{llllllllllllllll}\mathrm{N} & \mathrm{V} & \mathrm{K} & \mathrm{K} & \mathrm{E} & \mathrm{A} & \mathrm{L} & \mathrm{G} & \mathrm{I} & \mathrm{S} & \mathrm{R} & \mathrm{F} & \mathrm{S} & \mathrm{T} & \mathrm{Y} & \mathrm{E}\end{array}$

577 CAG CTT TGC AAA GTT GCA AGA GTC ATG GCA GCA AAG GAA TTC AAG TTT $\begin{array}{llllllllllllllll}Q & \mathrm{~L} & \mathrm{C} & \mathrm{K} & \mathrm{V} & \mathrm{A} & \mathrm{R} & \mathrm{V} & \mathrm{M} & \mathrm{A} & \mathrm{A} & \mathrm{K} & \mathrm{E} & \mathrm{F} & \mathrm{K} & \mathrm{F}\end{array}$

625 ACC GAC AGA TAC AAG AAG ATC TTT GAT GAA ACT GTA AAG ATC CTG ACT $\begin{array}{llllllllllllllll}T & D & R & Y & K & K & I & F & D & E & T & V & K & I & L & T\end{array}$

673 AAA TGC ACT CCT GGA ACT TCA GGT GCG GCT TCA TTG GTC AAG TTC AAC $\begin{array}{llllllllllllllll}K & C & T & P & G & T & S & G & A & A & S & L & V & K & F & N\end{array}$

721 GAA CAG ATC CAA ATT CTT GAA GGT GCT TTC GGT AAG ATT GTT GAA GAC

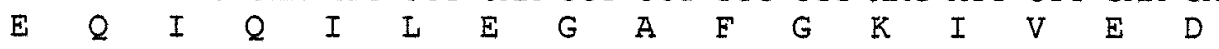

Fig. 3. Nucleotide sequence of the BR-10 $\mathrm{N}$ gene numbered from the ATG $\mathrm{N}$ gene, numbered from the ATG start codon. The deduced amino acid sequence of the protein encoded is written below the cDNA sequence. The asterisk $(*)$ indicates the TAA stop codon. 
number of transfers made and with increasing temperatures. The local as well as systemic responses of these hosts were also characteristic for some other tospoviruses. Disease symptoms (Fig. 1) on naturally infected onion plants were characterized by numerous necrotic eyelike spots on leaves and flower stems, followed by abortion of the flowers in the umbel, and finally resulted in death of flowers. However, these symptoms were not observed on onion plants that were inoculated with extracts from naturally infected plants.

No infections occurred after inoculation on Allium sativum cv. Nira, Beta vulgaris, Chenopodium murale, Citrulus lanatus, Cucurbita melo, C. pepo, Cucumis sativus, Helianthus annuus, Impatiens spp., Ipomoea setosa, Lycopersicon esculentum, Nicandra physaloides, Nicotiana glutinosa, $N$. occidentalis, $N$. tabacum cvs. TNN and Turkish, Petunia hybrida, Phaseolus vulgaris, Pisum sativum, Physalis floridana, Portulaca oleraceae, Vigna unguiculata, and Zinnia elegans.

Serology. Since the host range of BR-10 was limited compared with other tospoviruses, we concluded that BR-10 was distinct from other tospoviruses. To confirm identity of this virus, DAS-ELISA was performed on extracts of $N$. benthamiana plants, infected with tospoviruses TSWV, GRSV, TCSV, and INSV. IYSV was included in the analysis. No reaction was observed with any of the polyclonal antisera against TSWV, TCSV, GRSV, and INSV, but a strong positive reaction was obtained with IYSV (Fig. 2). No crossreactions were observed in a dot immunoblot assay of BR-10 with antiserum directed toward watermelon silver mottle virus (WSMV) and from two other distinct tospoviruses found in Brazil, isolated from chrysanthemum and zucchini (12, 25), respectively (data not shown).

Molecular size determination of the $\mathbf{N}$ protein. Purified nucleocapsid material, previously used for the production of a polyclonal anti-N serum of BR-10, was applied on a $12 \%$ polyacrylamide gel, and the size of the $\mathrm{N}$ protein was compared with sizes of the other tospovirus species, TSWV, TCSV, GRSV, and INSV. The $M_{\text {r }}$ of the $\mathrm{N}$ protein was estimated to be ap- proximately $32 \mathrm{kDa}$ (data not shown), which is larger than the $\mathrm{N}$ protein of most tospoviruses (4).

Cloning and sequence determination of the BR-10 $\mathbf{N}$ gene. Efforts to clone the BR-10 $\mathrm{N}$ gene by conventional cDNA synthesis failed, and therefore, attempts were made to obtain clones of the BR-10 N gene by means of PCR-amplification anticipating a close relationship with IYSV (2). Primers IY1 and IY2, bordering the $\mathrm{IYSV}_{\mathrm{NL}} \mathrm{N}$ gene, were used to prime firststrand cDNA synthesis followed by PCRamplification with the same primers. A fragment of about $850 \mathrm{bp}$ and of expected size for the putative $\mathrm{N}$ gene was obtained. After gel-purification and cloning into pGEM-T, the cloned fragment was checked for BR-10 S RNA specificity. Positive clones were selected and their nucleotide sequences determined. The BR-10 N gene fragment contained 825 nucleotides (Fig. 3 ), with an ATG start codon at position 1, and a TAA stop codon at position 820 , encoding for a protein of 273 amino acids, corresponding with a predicted $M_{\mathrm{r}}$ of 32 $\mathrm{kDa}$. Comparison of this gene with published sequences of other tospovirus $\mathrm{N}$ genes confirmed the identity of the sequence as the $\mathrm{N}$ gene. The $\mathrm{BR}-10 \mathrm{~N}$ protein was 15 amino acids larger than that of TSWV, TCSV, and GRSV, 13 amino acids larger than that of INSV, but 2 fewer than the $\mathrm{N}$ gene of GBNV and WSMV $(9,16,24,29,30)$, reflecting the difference in the molecular mass of the $\mathrm{N}$ protein of these viruses. The size of BR-10 N was the same as the IYSV N protein (2).

Comparison of the amino acid sequences of the $\mathrm{N}$ protein with the recognized species revealed a homology that ranged from 30 and $43 \%$ (Table 1), except for IYSV (2), which had a homology of $90.5 \%$ with BR-01.

\section{DISCUSSION}

During the last decade, the irrigated area in the São Francisco river basin has become an important region for growing vegetable crops such as onion, tomato, lettuce, and sweet pepper. This region is characterized by a semiarid climate with high temperatures that support high thrips populations throughout the year, therefore creating favorable conditions for tospovirus spread. Our work showed that the onion disease known as sapeca is always associated with a distinct tospovirus species. Serology and nucleotide sequences of the $\mathrm{N}$ gene of this virus showed a closer relationship with IYSV. Since the amino acid sequence identity between the BR-10 and $\mathrm{IYSV}_{\mathrm{NL}} \mathrm{N}$ genes is just above $90 \%$, which has been set as the threshold value below which isolates have to be regarded as distinct tospovirus species (14), the onion isolate BR-10 has to be considered a strain of IYSV. It has been designated $\mathrm{IYSV}_{\mathrm{BR}}$. However, considering the significant variation in the amino acid sequence, remarkably higher than the divergence of only 1 to $2 \%$ observed for strains of TSWV and 5 to $6 \%$ for GRSV $(5,9,11,17,19,21)$, the occurrence of both IYSV strains in Brazil and the Netherlands cannot be explained by a recent introduction of IYSV from one continent to another. The 9.5\% divergence (Fig. 4, Table 1 ) in the $\mathrm{N}$ protein may reflect an adaptation of the two strains to different environmental conditions. This adaptation is also supported by differences in host range and host response between the strains. $\mathrm{IYSV}_{\mathrm{BR}}$ systemically infected $N$. rustica, induced local lesions in Datura stramonium, and did not infect Petunia; while $\mathrm{IYSV}_{\mathrm{NL}}$ did not infect $N$. rustica, caused systemic infection in D. stramonium, and caused local lesions in Petunia. Those differences may be related to strain specificity or environmental conditions, but this needs to be confirmed. As with $\mathrm{IYSV}_{\mathrm{NL}}$, the Brazilian strain is more closely related to the Asian tospovirus species GBNV and WSMV than to any of the other tospovirus species (2). However, IYSV $\mathrm{BR}_{\mathrm{BR}}$ was distinct from a newly described Asian species, peanut yellow spot virus (PYSV), the most distinct tospovirus species reported (28).

Difficulties were encountered in reproducing the disease symptoms in onion under experimental conditions, although the virus was easily recovered by backinoculation. The absence of the original symptoms after inoculating onions could be an inherent property of this plant species, as Hall et al. (15) also encountered similar difficulties in confirming Koch's

Table 1. Amino acid sequence homology (\% identity) of the $\mathrm{N}$ gene of the established and proposed Tospovirus species

\begin{tabular}{|c|c|c|c|c|c|c|c|c|c|}
\hline & TSWV & GRSV & TCSV & INSV & GBNV & WSMV & PYSV & IYSV $_{\mathrm{NL}}$ & IYSV $_{\text {BR }^{*}}{ }^{*}$ \\
\hline TSWV & 100 & 78 & 77 & 55 & 33 & 33 & 24 & 34 & 35 \\
\hline GRSV & & 100 & 81 & 54 & 34 & 33 & 24 & 33 & 33 \\
\hline TCSV & & & 100 & 55 & 33 & 26 & 23 & 34 & 32 \\
\hline INSV & & & & 100 & 30 & 30 & 23 & 30 & 30 \\
\hline GBNV & & & & & 100 & 85 & 20 & 44 & 43 \\
\hline WSMV & & & & & & 100 & 23 & 44 & 43 \\
\hline PYSV & & & & & & & 100 & 21 & 21 \\
\hline $\mathrm{IYSV}_{\mathrm{NL}}$ & & & & & & & & 100 & 90 \\
\hline $\mathrm{IYSV}_{\mathrm{BR}}$ & & & & & & & & & 100 \\
\hline
\end{tabular}

a TSWV = tomato spotted wilt virus, GRSV = groundnut ringspot virus, TCSV = tomato chlorotic spot virus, INSV = impatiens necrotic spot virus, GBNV = groundnut bud necrosis virus, also referred as PBNV = peanut bud necrosis virus, WSMV = watermelon silver mottle virus, PYSV = peanut yellow spot virus, $\mathrm{IYSV}_{\mathrm{NL}}=$ iris yellow spot virus, $\mathrm{IYSV}_{\mathrm{BR}}=\mathrm{BR}-10$ onion isolate $(*$ access no. $\mathrm{AF067070)}$. 
postulates in studies to characterize a tospovirus also isolated from onion. This idea is supported by the observation that identical symptoms were observed on $N$. benthamiana plants irrespective of whether the plants were inoculated with sap from naturally infected onions or with sap from symptomless onion plants that had been inoculated with extracts from the naturally infected ones.

Although IYSV $\mathrm{BR}_{\mathrm{BR}}$ may have been present in Brazil for decades, since identical symptoms in onion fields were reported in 1981 (6), it is still difficult to establish its ecological niche. Preliminary investigations by our group have demonstrated that Thrips tabaci, the predominant thrips species colonizing onion plants in the region, efficiently transmits this onion isolate, whereas Frankliniella occidentalis and $F$. schultzei do not. Thrips tabaci also transmitted the IYSV strain found in the Netherlands (2). Further investigations are needed to determine the biological implications of the variability between the strains of IYSV, concerning virus-host and virus-vector interactions.

The economical impact of IYSV in iris and onion is low in the Netherlands, whereas this is not the case for IYSV $\mathrm{IR}_{\mathrm{BR}}$, which often causes $100 \%$ crop losses in Brazil. An analogous situation occurs in Israel, where a tospovirus isolate was found in onions that cross-reacted with the IYSV $_{\mathrm{NL}} \mathrm{N}$ antiserum from the Netherlands (13). The identification and characterization of IYSV $\mathrm{VR}_{\mathrm{BR}}$ as the most likely pathogen causing sapeca in onion provides valuable information for growers and extensionists to use in establishing programs to control the disease.

\section{ACKNOWLEDGMENTS}

We thank Tatsuya Nagata from Embrapa/Hortaliças for helpful suggestions and Mirtes Freitas Lima from Embrapa/Semi Árido for providing onion samples. We also thank Lucio Flavio Barbosa and Hamilton José Lourenço for their technical assistance. Luciana Pozzer from Universidade de Brasilia, Depto. de Biologia Celular, is a graduate research assistant supported by Conselho Nacional de Desenvolvimento Científico (CNPq), Brazil. A. C. de Ávila and R. O. Resende are supported by a research fellowship from CNPq.

\section{LITERATURE CITED}

1. Clark, M. F., and Adams, A. N. 1977. Characteristics of the microplate method of enzyme linked immunosorbent assay for the detection of plant viruses. J. Gen. Virol. 34:475-483.

2. Cortes, I., Livieratos, I. C., Derks, A., Peters, D., and Kormelink, R. 1998. Molecular and serological characterization of iris yellow spot virus, a new and distinct tospovirus species. Phytopathology 88:1276-1282.

3. Costa, A. S., and Forster, R. 1941. Identidade do vírus de vira-cabeça e sua inclusão no grupo do vírus de "spotted wilt." Bragantia 1:491-516.

4. de Ávila, A. C., de Haan, P., Kitajima, E. W., Kormelink, R., Resende, R. de O., Goldbach, R., and Peters, D. 1992. Characterization of a distinct isolate of tomato spotted wilt virus (TSWV) from Impatiens sp. in The Netherlands . J. Phytopathol. 134:133-151.

5. de Ávila, A. C., de Haan, P., Kormelink, R., Resende, R. de O., Goldbach, R. W., and Peters, D. 1993. Classification of tospovirus based on phylogeny of nucleoprotein gene sequences. J. Gen. Virol. 74:153-159.

6. de Ávila, A. C., Gama, M. I. C. S., Kitajima, E. W., and Pereira, W. 1981. Um vírus do grupo vira-cabeça do tomateiro isolado de cebola (Allium cepa L.). (Abstr.) Fitopatol. Bras. 6:525.

7. de Ávila, A. C., Huguenot, C., Resende, R. de O., Kitajima, E. W., Goldbach, R. W., and Peters, D. 1990. Serological differentiation of twenty isolates of tomato spotted wilt virus. J.
Gen. Virol. 71:2801-2807.

8. de Ávila, A. C., Lima, M. F., Resende, R. O., Pozzer, L., Ferraz, E., Maranhão, E. A. A. Candeia, J. A., and Costa, N. D. 1996. Identificação de tospovírus em hortaliças no Submédio São Francisco utilizando DAS-ELISA e dot-ELISA. Fitopatol. Bras. 21:503-508.

9. de Haan, P., Wagemakers, L., Peters, D., and Goldbach, R. 1990. The S RNA segment of tomato spotted wilt virus has an ambisense character. J. Gen. Virol. 71:1001-1007.

10. Devereux, J., Haeberli, P., and Smithies, O. 1984. A comprehensive set of sequence analysis programs for the VAX. Nucleic Acid Res. 12:387-395.

11. Dewey, R. A., Semorile, L., Grau, O., de Ávila, A. C., and Kitajima, E. W. 1995. Characterization of the $\mathrm{N}$ gene of a groundnut ringspot virus (GRSV) isolate from Argentina. J. Phytopathol. 143:713-717.

12. Duarte, L. M. L., Rivas, E. B., Alexandre, M. A. V., de Ávila, A. C., Nagata, T., and Chagas, C. M. 1995. Chrysanthemum stem necrosis caused by a possible novel tospovirus. J. Phytopathol. 143:569-571.

13. Gera, A., Cohen, J., Salomon, R., and Raccah, B. 1998. Iris yellow spot tospovirus detected in onion (Allium cepa) in Israel. Plant Dis. 82:127.

14. Goldbach, R., and Kuo, G. 1996. Introduction. International Symposium on Tospoviruses and Thrips of Floral and Vegetable Crops. Acta Hortic. 431:21-26.

15. Hall, J. M., Mohan, K., Knott, E. A., and Moyer, J. W. 1993. Tospoviruses associated with scape blight of onion (Allium cepa) seed crops in Idaho. Plant Dis. 77:952.

16. Heinze, C., Maiss, E., Adam, G., and Casper, R. 1995. The complete nucleotide sequence of the S RNA of a new Tospovirus species, representing serogroup IV. Phytopathology 85:683-690.

17. Kitajima, E. W., de Ávila, A. C., Resende, R. de O., Goldbach, R., and Peters, D. 1992 Comparative cytological and immunogold labelling studies on different isolates of tomato spotted wilt virus. J. Submicrosc. Cytol. Pathol. 24:1-14.

18. Law, M. D., and Moyer, J. W. 1990. A tomato

\begin{abstract}
BR-10 1 MATVRVKASE IEKLLSGGDA DVVIESDETE GFNFKS FVVA NEG IRMTFNN GYTILRNRAG IYKTIKSGKF IYSV $_{\mathrm{N}} 1$ MSTVRVKPSE IEKLLSGGDV DWIESDETE GFNFKN FVLA NEGVQMTFNN GYTILR NRAG IYKTIKTGKF
\end{abstract} BR-10 71 TFQNKP\|\|P SANVSPSQDD WTFRRLEGFI RARMLVELLE TKNEKEKQKM YEKICGLPLV SAYGLKPSDK IYSV $_{N} 71$ TFQGKT IVIP SANVSPNQDD WTFRRLEGFI RARMLVELIE TKDEKEKQKM YEKICGLPLV SAYGLKPSSK *** BR-10 141 FDATTARIML TLGGPLIL LA SLDSFAAAAL PLAYFQNVKK EALGISRFST YEQLCKVARV MAAKEFKFTD IYSV $_{\mathrm{N}} 141$ FHATTARIML TLGGPLTLMA SLDIFAAAAL PLAYFQNVKK EALGISRFST YEQLCKVARV MAAKEFKFTE *

\title{
BR-10 210 RYKKIFDETV KILTKCTPGT SGAASLVKFN EQIQILEGAF GKIVEDIGES SKPKNPSKKD RYN IYSV $_{\mathbf{N}} 210$ KYKKIFDET I KILTDCTPGT SGAASLIKFN EQIKILEGAF GKIVEDIGES SKPKTPSKKD RYN
}

Fig. 4. Comparison of amino acid sequence of BR-10 onion isolate and iris yellow spot virus (IYSV) from the Netherlands. Amino acid differences are shown by asterisk $(*)$. 
spotted wilt virus with a serologically distinct N protein. J. Gen. Virol. 71:933-938.

19. Maiss, E., Ivanova, L., Breyel, E., and Adam, G. 1991. Cloning and sequencing of the $\mathrm{S}$ RNA from a Bulgarian isolate of tomato spotted wilt virus. J. Gen. Virol. 72:461-464.

20. Nagata, T., de Ávila, A. C., Tavares, P. C. T., Barbosa, C. J., Juliatti, F. C., and Kitajima, E. W. 1995. Occurrence of different tospoviruses in six states of Brazil. Fitopatol. Bras. 20:90-95.

21. Pang, S.-Z., Slightom, J. L., and Gonsalves, D. 1993. The biological properties of a distinct tospovirus and sequence analysis of its $\mathrm{S}$ RNA. Phytopathology 83:728-733.

22. Pozzer, L., Nagata, T., Lima, M. I., Kitajima, E. W., Resende, R. de O., and de Ávila, A. C. 1994. "Sapeca": An onion disease in the SubMédio São Francisco region, Brazil, is caused by a tospovirus with a serologically distinct nucleocapsid protein. (Abstr.) Fitopatol. Bras. 19:321.
23. Pozzer, L., Resende, R. O., Bezerra, I. C., Nagata, T., Lima, M. I., Kitajima, E. W., and de Ávila, A. C. 1996. Zucchini lethal chlorotic virus (ZLCV), a proposed new species in the tospovirus genus. Fitopatol. Bras. $21: 432$.

24. Reddy, D. V. R., Ratna, A. S., Sudarshana, M. R., Poul, F., and Kiran-Kumar, I. 1992. Serological relationships and purification of bud necrosis virus, a tospovirus occurring in peanut (Arachis hypogaea L.) in India. Ann. Appl. Biol. 120:279-286.

25. Resende, R. O., Pozzer, L., Nagata, T., Bezerra, I. C., Lima, M. I., Giordano, L. B., Kitajima, E. W., and de Ávila, A. C. 1996. New tospoviruses found in Brazil. Acta Hortic. 431:78-81.

26. Sambrook, J., Fritsch, E. F., and Maniatis, T. 1989. Molecular Cloning: A Laboratory Manual. 2nd ed. Cold Spring Harbor Laboratory, Cold Spring Harbor, NY.
27. Sanger, F, Nicklen, S, and Coulson, A. R. 1977. DNA sequencing with chain-terminating inhibitors. Proc. Natl. Acad. Sci. USA 74:5463-5467.

28. Satyanarayana, T., Gowda, S., Reddy, K. L., Mitchell, S. E., Dawson, W. O., and Reddy, D.

V. R. 1998. Peanut yellow spot virus is a member of a new serogroup of Tospovirus genus based on small (S) RNA sequence and organization. Arch. Virol. 143:353-364.

29. Satyanarayana, T., Mitchell, S. E., Reddy, D. V. R., Brown, S., Kresovich, S., Jarret, R. Naidu, R. A., and Demski, J. W. 1996. Peanut bud necrosis tospovirus S RNA: Complete nucleotide sequence, genome organization and homology to other tospoviruses. Arch. Virol. 141:85-98.

30. Yeh, S. D., and Chang, T. F. 1995. Nucleotide sequence of the $\mathrm{N}$ gene of watermelon silver mottle virus, a proposed new member of the genus Tospovirus. Phytopathology 85:58-64. 